\title{
THE EFFECT OF DILUTION ON THE CONCENTRATION OF SODIUM, POTASSIUM, CALCIUM AND MAGNESIUM IN RAM AND BULL SPERMATOZOA
}

\author{
P. J. QUINN, I. G. WHITE AND B. R. WIRRIGK \\ Department of Veterinary Physiology, University of Sydney, \\ Sydney, Australia
}

(Received 15th Fune 1965, revised 26th October 1965)

Summary. Mild dilution $(<1 \cdot 8)$ of ram and bull semen in isotonic sodium phosphate diluent of $\mathrm{pH} 7.0$ caused an influx of sodium and an efflux of potassium, calcium and magnesium from the spermatozoa. Equilibrium was reached soon after dilution and little further change in the concentration of these cations was observed over $3 \mathrm{hr}$.

Similar changes occurred when ram and bull semen was diluted in tris and veronal diluents of $\mathrm{pH} \mathrm{7;} \mathrm{however,} \mathrm{calcium} \mathrm{was} \mathrm{found} \mathrm{to}$ accumulate in ram spermatozoa diluted in tris. Diluting semen in buffers of $\mathrm{pH}$ range 8.5 to 5.5 indicated that potassium loss from the spermatozoa increased with increasing $\mathrm{pH}$.

Greater dilution (1:100) and exhaustive washing (four times) had a similar but more severe effect on the cation concentration of ram and bull spermatozoa. A large influx of sodium was accompanied by a marked depletion of potassium which tended to be further depleted over $3 \mathrm{hr}$.

\section{INTRODUCTION}

When mammalian semen is excessively diluted or washed, even in an isotonic medium containing a glycolysable sugar, the viability of the spermatozoa is impaired (Milovanov, 1934; Chang, 1947, 1949; Emmens \& Swyer, 1948; Blackshaw, 1953a, b; White, 1953c, d). This is probably due to the removal of essential components from inside the cell (cf. also White, 1953a, b). A number of other authors have also demonstrated the beneficial effect of potassium on the viability of washed or diluted spermatozoa (Wales \& White, 1958a, b, 1961, 1963; Dott \& White, 1964; Wallace \& Wales, 1964) and it has been suggested that potassium may be one of the important substances lost from spermatozoa.

The potassium concentration is greater in spermatozoa than in the seminal plasma (Cragle, Salisbury \& Muntz, 1958; Cragle, Salisbury \& VanDemark, 1958; Quinn, White \& Wirrick, 1965) and potassium is lost from ram spermatozoa even when the semen is subjected to very mild dilutions in a sodium phosphate buffer (Dott \& White, 1964). This paper is concerned with further 
studies on the effect of dilution on the potassium, sodium, calcium and magnesium content of ram and bull spermatozoa.

\section{MATERIALS AND METHODS}

Ram semen was collected by electrical ejaculation using the method of Blackshaw (1954) and bull semen using an artificial vagina. Cold shocking of the semen was avoided and only samples of good initial motility were used.

Aliquots $(0.5$ to $1.0 \mathrm{ml})$ of semen-either neat or diluted up to $1: 8$-were centrifuged in special tapering centrifuge tubes to separate the spermatozoa (Quinn et al., 1965). The 1:100 dilution was made in large centrifuge tubes and the spermatozoa spun down to about $5 \mathrm{ml}$ before transferring to the special tubes for further centrifuging. Spermatozoa were washed by diluting $0.5 \mathrm{ml}$ of semen to $4.5 \mathrm{ml}$ and centrifuging at $1700 \mathrm{rev} / \mathrm{min}$ for $10 \mathrm{~min}$ and withdrawing the supernatant (White, 1953a); this procedure was repeated four times.

An atomic absorption spectrophotometer was used for the analysis of sodium, potassium, calcium and magnesium (Quinn et al., 1965).

Dott \& White's (1964) 0.08 м-phosphate diluent was used for diluting ram semen. This concentration of phosphate was found to depress the motility of bull spermatozoa and $0.02 \mathrm{M}$-phosphate was therefore used routinely for this species. The $0.08 \mathrm{M}$-sodium phosphate diluents consisted of $0.048 \mathrm{M}-\mathrm{Na}_{2} \mathrm{HPO}_{4}$. $12 \mathrm{H}_{2} \mathrm{O}, 0.032 \mathrm{~m}-\mathrm{NaH}_{2} \mathrm{PO}_{4} \cdot \mathrm{H}_{2} \mathrm{O}, 0.040 \mathrm{M}-\mathrm{NaCl},(\mathrm{pH} 7)$, and $0.0008 \mathrm{M}-$ $\mathrm{Na}_{2} \mathrm{HPO}_{4} \cdot 12 \mathrm{H}_{2} \mathrm{O}, 0.079 \mathrm{M}-\mathrm{NaH}_{2} \mathrm{PO}_{4} \cdot \mathrm{H}_{2} \mathrm{O}, 0.072 \mathrm{M}-\mathrm{NaCl}$, (pH 5.5). The $0.02 \mathrm{M}$-phosphate diluents contained a quarter of the concentration of the mono- and di-sodium phosphate and $0.120 \mathrm{M}$ and $0.144 \mathrm{M}-\mathrm{NaCl}$ for $\mathrm{pH} 7$ and $5 \cdot 5$ respectively.

Tris- $\mathrm{HCl}$ diluent consisted of $0.042 \mathrm{M}$-tris [tris-(hydroxy-methyl)-aminomethane]; $0.038 \mathrm{~m}-\mathrm{HCl}, \mathrm{pH} \mathrm{7}$ ), and $0.062 \mathrm{~m}$-tris; $0.019 \mathrm{~m}-\mathrm{HCl}$, (pH 8.5). $0.104 \mathrm{M}-\mathrm{NaCl}$ was added to both. Veronal-HCl diluent of $\mathrm{pH} 7$ consisted of $0.0033 \mathrm{M}$-sodium diethyl-barbiturate; $0.030 \mathrm{M}-\mathrm{HCl}$ and $0.080 \mathrm{M}-\mathrm{NaCl}$. Fructose $(400 \mathrm{mg} / 100 \mathrm{ml})$ was added to all diluents as a substrate for the spermatozoa and the final mixtures were isotonic with $0.9 \% \mathrm{NaCl}$.

The statistical significance of the results has been assessed by an analysis of variance, often using the sILLIAC electronic computer. The interaction mean square has been used to calculate the standard errors (S.E.) of the differences between means as presented in the tables, and this has been used for the $t$-test.

\section{RESULTS}

\section{Effect of dilution in phosphate buffer}

Ram and bull semen were diluted two-, four- and eight-fold in sodium phosphate buffer of $\mathrm{pH} 7$ and the spermatozoa immediately separated from the supernatant. The concentrations of sodium, potassium, calcium and magnesium in the spermatozoa at each dilution are presented in Table 1 (Experiment 1).

Sodium accumulates in the spermatozoa on dilution and potassium, calcium and magnesium are lost, the effects being more marked with increasing dilution. The exchanges of sodium, potassium and magnesium are similar for ram and bull spermatozoa. However, the calcium content of undiluted bull spermatozoa $(29.6 \mathrm{mg} / 100 \mathrm{~g})$ is higher than $\mathrm{ram}(10.1 \mathrm{mg} / 100 \mathrm{~g})$, but they become similar 
(7.1 and $10.4 \mathrm{mg} / 100 \mathrm{~g}$ respectively) on $1: 8$ dilution. The loss of calcium is thus much greater with bull spermatozoa.

The influx of sodium at a dilution of $1: 8$ (29 and 50 m-equiv/l for ram and bull respectively) is almost twice the combined loss of potassium, calcium and magnesium (15 and $28 \mathrm{~m}$-equiv/l for ram and bull respectively).

\section{Effect of time on dilution changes}

Ram and bull semen were diluted 1:2 in sodium phosphate diluents of $\mathrm{pH} 7$ and cation analyses were made on the spermatozoa initially and at hourly intervals for $3 \mathrm{hr}$ at room temperature $\left(15\right.$ to $\left.20^{\circ} \mathrm{G}\right)$. The results for the diluted and neat semen samples are summarized in Table 1 (Experiment 2).

TABLE 1

GONCENTRATION $(\mathrm{mg} / 100 \mathrm{~g}$ ) OF CATIONS IN SPERMATOZOA AFTER DILUTING SEMEN IN SODIUM PHOSPHATE BUFFERS $(\mathrm{pH} 7 \cdot 0)$

\begin{tabular}{|c|c|c|c|c|c|c|}
\hline Experiment & Species & Treatment & Sodium & Potassium & Calcium & Magnesium \\
\hline 1 & $\begin{array}{l}\text { Ram } \\
\text { (seven replicates) } \\
\\
\text { Bull } \\
\text { (four replicates) }\end{array}$ & $\begin{array}{l}\text { Undiluted } 0 \mathrm{hr} \\
1: 2 \text { dilution } 0 \mathrm{hr} \\
1: 4 \text { dilution } 0 \mathrm{hr} \\
1: 8 \text { dilution } 0 \mathrm{hr} \\
\\
\text { Undiluted } 0 \mathrm{hr} \\
1: 2 \text { dilution } 0 \mathrm{hr} \\
1: 4 \text { dilution } 0 \mathrm{hr} \\
1: 8 \text { dilution } 0 \mathrm{hr}\end{array}$ & $\begin{array}{c}109 \\
167^{* *} \\
180^{* *} \\
175^{* *} \\
\text { S.E. }=20 \\
122 \\
183^{*} \\
170 \\
234^{* *} \\
\text { S.E. }=26\end{array}$ & $\begin{array}{c}141 \\
118 \\
109^{*} \\
96^{* *} \\
\text { S.E. }=12 \\
159 \\
133 \\
100^{* *} \\
92^{* *} \\
\text { S.E. }=15\end{array}$ & $\begin{array}{c}10 \cdot 1 \\
7 \cdot 2 \\
8 \cdot 1 \\
7 \cdot 1 \\
\text { S.E. }=2 \cdot 4 \\
29 \cdot 6 \\
17 \cdot 7^{*} \\
9 \cdot 9^{* *} \\
10 \cdot 4^{* *} \\
\text { S.E. }=5 \cdot 3\end{array}$ & $\begin{array}{c}15 \cdot 1 \\
12 \cdot 2 \\
12 \cdot 5 \\
10 \cdot 4^{*} \\
\text { S.E. }=1 \cdot 7 \\
15 \cdot 6 \\
11 \cdot 4^{*} \\
9 \cdot 9^{* *} \\
8 \cdot 5^{* *} \\
\text { S.E. }=1 \cdot 3\end{array}$ \\
\hline 2 & $\begin{array}{l}\text { Ram } \\
\text { (nine replicates) } \\
\text { Bull } \\
\text { (six replicates) }\end{array}$ & \begin{tabular}{|rr} 
Undiluted & $0 \mathrm{hr}$ \\
$1: 2$ dilution & $0 \mathrm{hr}$ \\
$1 \mathrm{hr}$ \\
$2 \mathrm{hr}$ \\
$3 \mathrm{hr}$ \\
\\
\\
\\
Undiluted & $0 \mathrm{hr}$ \\
$1: 2$ dilution & $0 \mathrm{hr}$ \\
$1 \mathrm{hr}$ \\
$2 \mathrm{hr}$ \\
$3 \mathrm{hr}$
\end{tabular} & $\begin{array}{c}116^{* *} \\
192 \\
159^{*} \\
174 \\
169 \\
\text { S.E. }=14 \\
125^{*} \\
202 \\
201 \\
235 \\
189 \\
\text { S.E. }=34\end{array}$ & $\begin{array}{c}135^{* *} \\
95 \\
89 \\
99 \\
81 \\
\text { S.E. }=7 \\
227 * * \\
138 \\
145 \\
148 \\
131 \\
\text { S.E. }=24\end{array}$ & $\begin{array}{c}8 \cdot 1^{* *} \\
5 \cdot 4 \\
5 \cdot 5 \\
7 \cdot 2 \\
75^{*} \\
\text { S.E. }=0 \cdot 8 \\
25 \cdot 2^{* *} \\
15 \cdot 2 \\
11 \cdot 7 \\
9 \cdot 0^{*} \\
8 \cdot 9^{*} \\
\text { S.E. }=3 \cdot 0\end{array}$ & $\begin{array}{c}13 \cdot 7 \\
12 \cdot 8 \\
12 \cdot 1 \\
14 \cdot 1 \\
14 \cdot 3 \\
\text { S.E. = } 1 \cdot 6 \\
13.3 \\
11 \cdot 6 \\
11.5 \\
9.9 \\
9 \cdot 5 \\
\text { S.E. }=1.5\end{array}$ \\
\hline
\end{tabular}

* $P<0.05 ; * * P<0.01$ (probability of treatment being different from undiluted in Experiment 1 and diluted $0 \mathrm{hr}$ in Experiment 2).

As in the previous experiment there was a rise in sodium and a fall in potassium, calcium and magnesium, but the effect was usually immediate and there was little further change during the 3-hr incubation.

\section{Effect of dilution in different buffers}

Ram and bull semen were diluted $1: 8$ and $1: 4$ respectively in phosphate, tris and veronal buffers of $\mathrm{pH} 7$ and the concentrations of sodium, potassium, calcium and magnesium were determined.

Table 2 (Experiment 3) shows that tris and veronal buffers, like phosphate, 


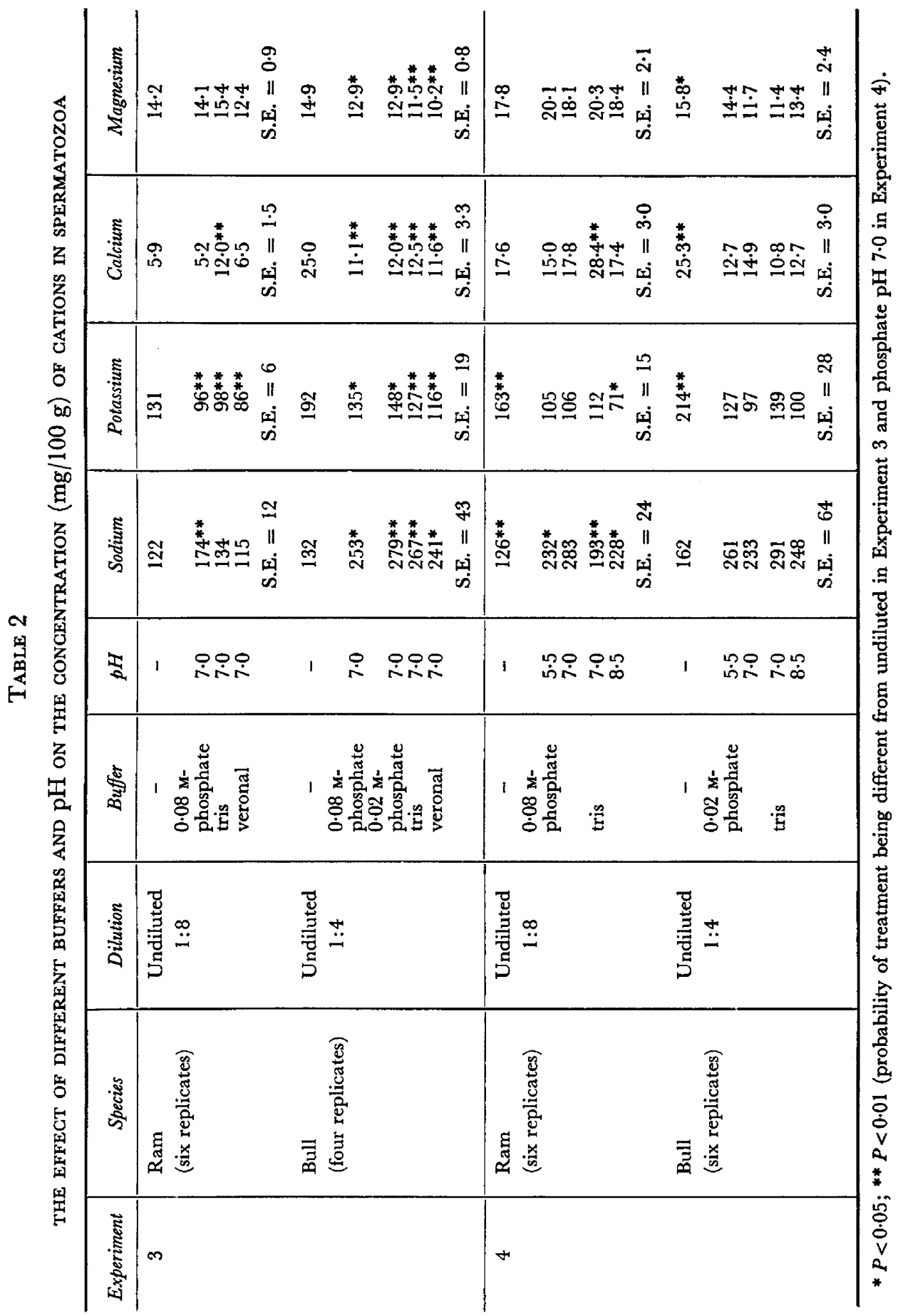


all caused a significant increase in the sodium concentration of bull spermatozoa and a decrease in potassium, calcium and magnesium. The rise in the sodium concentration of ram spermatozoa was less with tris and veronal, although all three buffers gave a comparable depression of potassium and had no significant effect on magnesium. Diluting ram spermatozoa in tris caused, surprisingly, an increase in the calcium content.

Diluting ram and bull semen in the veronal diluent and bull semen in the $0.08 \mathrm{M}$-phosphate diluent considerably depressed the motility of the spermatozoa.

\section{Effect of $p H$ on diluted spermatozoa}

The effect of the $\mathrm{pH}$ of the diluent on the concentration of the major cations in diluted ram and bull spermatozoa is shown in Table 2 (Experiment 4). Two buffers were used, phosphate and tris, to give $\mathrm{pH}$ values of 5.5, 7.0 and 8.5; both buffers were used at the overlapping $\mathrm{pH}$ of 7.0 to control any differences due to the buffer rather than to $\mathrm{pH}$.

The most consistent effect is that potassium loss tends to increase with increasing $\mathrm{pH}$. Thus potassium values are lower at 8.5 than at 7.0 for ram and bull spermatozoa diluted in tris and lower at 7.0 and 5.5 for bull spermatozoa diluted in phosphate.

There is also evidence of a reverse effect of $\mathrm{pH}$ on the sodium concentration of ram spermatozoa; thus the sodium values are higher at 8.5 than at 7.0 for tris and higher at 7.0 than 5.5 in phosphate. As in the previous experiment, sodium influx is less for ram spermatozoa diluted in tris than in phosphate at $\mathrm{pH} 7 \cdot 0$. Again there was an accumulation of calcium when ram spermatozoa was diluted in tris at $\mathrm{pH} 7.0$. However, at $\mathrm{pH} 8.5$ there was no accumulation of this cation.

\section{Effect of high dilution and severe washing}

The cation concentration of ram and bull spermatozoa after high dilution $(1: 100)$ and after washing four times in a phosphate buffer is shown in Table 3. Analyses were made directly after diluting or washing and again after incubation for $3 \mathrm{hr}$ at $37^{\circ} \mathrm{C}$. The results were subject to analysis of variance isolating sums of squares due to differences between treatments, hours, ejaculates and their interactions. The second order interaction has been used to calculate the standard error, used in the $t$-test.

High dilution and severe washing have similar effects on the cation concentration of spermatozoa. Both procedures caused a considerable increase in sodium and a marked depletion of potassium, which was often accentuated by incubating the spermatozoa for $3 \mathrm{hr}$. There was also a decrease in the calcium and magnesium concentration of bull spermatozoa as previously observed at lower dilutions.

\section{DISCUSSION}

These studies confirm the finding of Dott \& White (1964) that a $1: 2$ dilution of ram semen in sodium phosphate buffer causes a marked fall in the potassium concentration within the spermatozoa. A similar effect is seen with bull spermatozoa and with both species there is an efflux of calcium and magnesium as 
well as potassium. From the results of Quinn et al. (1965) on the distribution of potassium, calcium and magnesium between spermatozoa and seminal plasma, it is clear that the concentration of all three cations will be considerably less in the surrounding medium than in the spermatozoa after a $1: 2$ dilution. The efflux of these ions is, therefore, in the direction of the lessening concentration gradient.

The compensatory movement of sodium into the spermatozoa is also along a lessening concentration gradient, since the sodium concentration of the diluents greatly exceeds that of the undiluted ram and bull spermatozoa (Quinn et al., 1965).

\section{TABLE 3}

CONCENTRATION (mg/100 g) OF CATIONS IN SPERMATOZOA AFTER WASHING FOUR TIMES AND 1:100 DILUTION. SODIUM PHOSPHATE DILUENT OF $\mathrm{pH}=7.0$ WAS USED AND ANALYSES ARE MADE IMMEDIATELY AND AFTER $3 \mathrm{hr}$

\begin{tabular}{|c|c|c|c|c|c|c|}
\hline Species & Time & Treatment & Sodium & Potassium & Calcium & Magnesium \\
\hline \multirow[t]{3}{*}{$\begin{array}{l}\text { Ram } \\
\text { (four replicates) }\end{array}$} & $0 \mathrm{hr}$ & $\begin{array}{l}\text { Undiluted } \\
\text { Washed } \\
\text { Diluted }\end{array}$ & $\begin{array}{l}103 \\
361^{* *} \\
308^{* *}\end{array}$ & $\begin{array}{l}87 \\
22 * * \\
32 * *\end{array}$ & $\begin{array}{l}6 \cdot 0 \\
4 \cdot 2 \\
6 \cdot 1\end{array}$ & $\begin{array}{r}7 \cdot 7 \\
7 \cdot 5 \\
11 \cdot 0\end{array}$ \\
\hline & $3 \mathrm{hr}$ & $\begin{array}{l}\text { Undiluted } \\
\text { Washed } \\
\text { Diluted }\end{array}$ & $\begin{array}{l}117 \\
380^{* *} \\
479^{* *}\end{array}$ & $\begin{array}{l}91 \\
5^{* *} \\
4^{* *}\end{array}$ & $\begin{array}{l}5.7 \\
3.7 \\
3.5\end{array}$ & $\begin{array}{l}8 \cdot 0 \\
4 \cdot 1 \\
3 \cdot 6\end{array}$ \\
\hline & & & S.E. $=33.4$ & S.E. $=6 \cdot 3$ & S.E. $=1.78$ & S.E. $=1.93$ \\
\hline \multirow[t]{3}{*}{$\begin{array}{l}\text { Bull } \\
\text { (five replicates) }\end{array}$} & $0 \mathrm{hr}$ & $\begin{array}{l}\text { Undiluted } \\
\text { Washed } \\
\text { Diluted }\end{array}$ & $\begin{array}{l}132 \\
187 \\
258\end{array}$ & $\begin{array}{l}230 \\
40^{* *} \\
13^{* *}\end{array}$ & $\begin{array}{l}39 \cdot 3 \\
6 \cdot 0^{* *} \\
2 \cdot 8^{* *}\end{array}$ & $\begin{array}{l}18 \cdot 1 \\
9 \cdot 2^{* *} \\
4 \cdot 7^{* *}\end{array}$ \\
\hline & $3 \mathrm{hr}$ & $\begin{array}{l}\text { Undiluted } \\
\text { Washed } \\
\text { Diluted }\end{array}$ & $\begin{array}{l}131 \\
224 \\
318\end{array}$ & $\begin{array}{c}195 \\
33^{* *} \\
46^{* *}\end{array}$ & $\begin{array}{l}39 \cdot 0 \\
3 \cdot 3^{* *} \\
8 \cdot 3^{* *}\end{array}$ & $\begin{array}{l}28 \cdot 6 \\
6 \cdot 3^{* *} \\
15 \cdot 0^{*}\end{array}$ \\
\hline & & & S.E. $=89 \cdot 2$ & S.E. $=13.4$ & S.E. $=5.90$ & S.E. $=4.94$ \\
\hline
\end{tabular}

$* P<0.05 ; * * P<0.01$ (significantly different from undiluted).

The marked depletion of potassium in spermatozoa on diluting 1:100 or exhaustive washing is consistent with reports that such treatment has a detrimental effect on the motility of ram and bull spermatozoa. This effect can be reduced by including potassium in the sodium phosphate diluent (White, 1953b; Dott \& White, 1964). Potassium must, however, fall to very low levels (see Table 3) before motility is impaired. Milder treatments, such as a $1: 2$ dilution of ram semen in sodium phosphate, reduce the potassium concentration of the spermatozoa from 141 to $118 \mathrm{mg} / 100 \mathrm{~g}$ (Table 1), and yet motility and impedance frequency change are not greatly affected by this treatment (Dott \& White, 1964).

Although phosphate is not specific in its effect on the spermatozoa, the cation concentration of the diluted cells was to some extent dependent on the diluent used. Sodium influx into ram spermatozoa was greater in phosphate than in tris buffer, due probably to a lower sodium concentration in the latter diluent ( $386 \mathrm{mg} / 100 \mathrm{~g}$ compared with $240 \mathrm{mg} / 100 \mathrm{~g}$ ). A more puzzling observation was the increase in the calcium content of ram spermatozoa produced by tris at $\mathrm{pH} 7 \cdot 0$ but not at 8.5 . 
The injurious effect of high concentrations of phosphate on the oxidative metabolism of bull spermatozoa has been previously reported (Bishop \& Salisbury, 1955; Salisbury \& Nakabayashi, 1957; White, 1957; Lodge, Salisbury, Schmidt \& Graves, 1963), but the adverse effect on motility has apparently escaped notice. A 1:2 dilution of ram and bull semen in the veronal buffer immediately halved the motility of the spermatozoa. Barbiturates have been shown to uncouple oxidative phosphorylation in liver mitochondria (Aldridge \& Parker, 1960), but the adverse effect on the motility of spermatozoa in this instance is probably more direct. At lower concentrations veronal has been used as a diluent for spermatozoa (Blackshaw, 1953a; Wales \& White, 1958c).

The observation that acid conditions decrease the loss of potassium from spermatozoa may be of some physiological significance in maintaining intracellular potassium levels and may, in part, explain why there is little loss of potassium when undiluted semen samples are incubated for several hours.

\section{ACKNOWLEDGMENTS}

The authors are indebted to Professor C. W. Emmens for his interest and advice. The work has been aided by grants from the Ford Foundation, the Australian Wool Board, the Rural Credits Development Fund of the Commonwealth Bank of Australia and the Australian Dairy Board.

\section{REFERENCES}

Aldridge, W. N. \& Parker, V. H. (1960) Barbiturates and oxidative phosphorylation. Biochem. $\mathcal{F}$. $76,47$.

Bishop, M. W. H. \& Salisbury, G. W. (1955) Effect of dilution with saline and phosphate solutions on oxygen uptake of bull semen. Am. F. Physiol. 181, 114.

Blackshaw, A. W. (1953a) The effects of potassium and calcium salts on the motility of ram, rabbit and bull spermatozoa. 7. Physiol., Lond. 120, 465.

Blackshaw, A. W. (1953b) The motility of ram and bull spermatozoa in dilute suspension. J. gen. Physiol. 36, 449.

Blackshaw, A. W. (1954) A bipolar rectal electrode for the electrical production of ejaculation in sheep. Aust. vet. F. 30, 249.

Chang, M. C. (1947) Effects of testis hyaluronidase and seminal fluids on the fertilizing capacity of rabbit spermatozoa. Proc. Soc. exp. Biol. Med. 66, 51.

Chang, M. C. (1949) Effects of heterologous seminal plasma and sperm cells on fertilizing capacity of rabbit spermatozoa. Proc. Soc. exp. Biol. Med. 70, 32.

Cragle, R. G., Salisbury, G. W. \& Muntz, T. H. (1958) Distribution of bulk and trace minerals in bull reproductive tract fluids and semen. F. Dairy Sci. 41, 1273.

Cragle, R. G., Salisbury, G. W. \& VanDemark, N. L. (1958) Sodium, potassium, calcium and chloride distribution in bovine semen. 7. Dairy Sci. 41, 1267.

DotT, H. M. \& WhITE, I. G. (1964) Effect of potassium on ram spermatozoa studied by a flow dialysis technique. F. Reprod. Fert. 7, 127.

Emmens, C. W. \& SWYer, G. I. M. (1948) Observations on the motility of rabbit spermatozoa in dilute suspension. F. gen. Physiol. 32, 121.

Lodge, J. R., Salisbury, G. W., Schmidt, R. P. \& Graves, C. N. (1963) The effect of phosphate and related co-factors on the metabolism of bovine spermatozoa. F. Dairy Sci. 46, 473.

Mroovanov, V. K. (1934) Osnovy iskusstvennogo osemenenija. Principles of artificial insemination. State Publishing House, Moscow-Leningrad.

QuinN, P. J., WhITE, I. G. \& WIRRIck, B. R. (1965) Studies of the distribution of the major cations in semen and male accessory secretions. F. Reprod. Fert. 10, 379.

Salisbury, G. W. \& Nakabayashi, N. T. (1957) Effect of phosphate and chloride ions on aerobic metabolism of bovine spermatozoa. F. exp. Biol. 34, 52 .

WALES, R. G. \& WhITE, I. G. (1958a) The effect of ions of the alkali metals, magnesium, and calcium on dog spermatozoa. F. Physiol., Lond. 142, 494. 
WALEs, R. G. \& White, I. G. (1958b) The effect of alkali metal, magnesium, and calcium ions on the motility of fowl spermatozoa. Aust. F. biol. Sci. 11, 589.

WALES, R. G. \& WhITE, I. G. (1958c) The interaction of $\mathrm{pH}$, tonicity and electrolyte concentration on the motility of dog spermatozoa. F. Physiol., Lond. 141, 273.

Wales, R. G. \& Whrte, I. G. (1961) The viability of fowl spermatozoa in dilute suspension. Aust. $\mathcal{J}$. biol. Sci. 14, 637.

Wales, R. G. \& WhITE, I. G. (1963) Viability of diluted dog spermatozoa in vitro. F. Reprod. Fert. 5, 67.

Wallace, J. G. \& WalEs, R. G. (1964) Effect of ions on the metabolism of ejaculated and epididymal ram spermatozoa. F. Reprod. Fert. 8, 187.

Whrte, I. G. (1953a) The effect of washing on the motility and metabolism of ram, bull and rabbit spermatozoa. 7. exp. Biol. 30, 200.

WhITE, I. G. (1953b) The effect of potassium on the washing and dilution of mammalian spermatozoa. Aust. F. exp. Biol. 31, 193.

Whrte, I. G. (1953c) Metabolic studies of washed and diluted ram and bull spermatozoa. Aust. F. biol. Sci. 6, 706.

White, I. G. (1953d) Studies on the alkali metal requirements of ram and bull spermatozoa. Aust. 7 . biol. Sci. 6, 716 .

WhITE, I. G. (1957) Metabolism of glycerol and similar compounds by bull spermatozoa. Am. $\mathcal{J}$. Physiol. 189, 307. 